\author{
B. R. Rakishev ${ }^{1}$, Acad. of the National Academy \\ of Sciences of Kazakhstan, Dr. Sc. (Tech.), Prof., \\ orcid.org/0000-0001-5445-070X, \\ V. I. Bondarenko ${ }^{2}$, Dr. Sc. (Tech.), Prof., \\ orcid.org/0000-0001-7552-0236, \\ M. M. Matayev ${ }^{3}$, Dr. Sc. (Chem.), Prof., \\ orcid.org/0000-0002-9057-5443, \\ Z.S. Kenzhetayev ${ }^{1}$, \\ orcid.org/0000-0003-2009-6655
}

1 - Satbayev University, Almaty, the Republic of Kazakhstan, e-mail: kzhiger@yahoo.com

2 - Dnipro University of Technology, Dnipro, Ukraine, e-mail: v_domna@yahoo.com

3 - "Institute of High Technologies" LLP, Almaty, the Republic of Kazakhstan, e-mail: mataev_06@mail.ru

\title{
INFLUENCE OF CHEMICAL REAGENT COMPLEX ON INTENSIFICATION OF URANIUM WELL EXTRACTION
}

Purpose. To determine the effect of special chemical reagents in the composition of leaching solutions on geotechnological parameters during uranium well extraction. To study the possibility of applying this method to increase efficiency of well extraction of uranium ores by intensifying ecotechnological processes of underground uranium leaching. To ensure design capacity of producing blocks and the completeness of extracting metal from them, reduce and prevent sediment in porous medium, reduce specific consumption of sulfuric acid, electric power, labor and other production costs in the process of uranium well extraction.

Methodology. The research includes consistent literature review, laboratory and practical studies in real conditions. The samples studied in the laboratory by X-ray phase analysis of mineralogical characteristics of sedimentation were taken from Syrdarya depression. Chemical reagents were selected and tested in geotechnological wells during experimental extraction of uranium. The resulting geotechnological parameters of wells were compared to experimental data.

Findings. Values of $\mathrm{pH}$ parameters of leaching solutions were obtained within the range from 6.5 to 2.3 ; it was established that Eh values initially tend to increase sharply to $300-380 \mathrm{mV}$ and then to decrease to $170 \mathrm{mV}$; uranium content in productive solution was consistently growing from 29 to $146 \mathrm{mg} / \mathrm{l}$; the values of iron salts $\left(\mathrm{Fe}^{3+}, \mathrm{Fe}^{2+}\right)$ concentration in the productive solution were determined in the case when they were affected by chemical multifunctional reagents.

Originality. The method for intensification of uranium well extraction has been developed and justified. It is based on a new complex of chemical reagents producing a selective effect on uraniferous minerals, which improves performance of producing blocks.

Practical value. Rationally selected oxidizer and chemical reagents, as well as the scheme of their feeding into the productive horizon allow intensifying solution of four-valent uranium in complex mining and geological conditions by underground leaching and improving performance of the producing block.

Keywords: well extraction, uranium ore, sedimentation, $X$-ray phase analysis, chemical reagents

Introduction. At present, various kinds of minerals are mined not only by conventional methods of mining [1, 2], but also - more and more widely - by geotechnological ones, especially well mining, which is used for the development of low quality and low-grade deposits [3, 4]. Geotechnological methods of mining are applicable when developing non-renewable energy sources, primarily gas and hydrate deposits containing mammoth volumes of compressed methane [5].

The technology of uranium well extraction involves pumping out productive solutions (PS) from the recovery wells of the producing block, sorptive extraction of uranium from solutions, lighting the master batch with subsequent fortification with concentrated sulfuric acid, feeding acidified leaching solution (LS) through injection wells into the ore body of the block [6]. The unquestionable advantage of such mining method - in comparison to conventional methods - is prevention of rock waste accumulation on the earth's surface [7, 8]. The processing waste can be used as a component for solidifying mixtures to fill underground cavities [9]. At the same time, leaching is the main operation of preparing uranium ore for extraction, as it determines the quantity and cost of the final product. The use of sulfuric acid as a reagent solvent at enterprises of Kazakhstan is explained by its low cost, availability, the possibility of relatively complete transfer of uranium into the solution [10]. However, the high kinetics of sulfuric acid interaction with feldspar and carbonate minerals of ore-bearing rocks in difficult geological conditions causes sedimentation in the form of a geochemical barrier that impedes the leaching process.

(C) Rakishev B. R., Bondarenko V. I., Matayev M. M., Kenzhetayev Z. S., 2019
Poorly soluble sediments and dislocated clay particles in the productive horizon increase hydraulic resistance and form impermeable areas of the geochemical barrier that overlap the flow lines of solutions. As a rule, decrease in the filtration characteristics of the productive horizon leads to decrease in the uranium content in the PS, reduction in the productivity and injectivity of wells as a result of a decreased period of uninterrupted well operation [11]. Hence, the period of adjusting producing blocks grows, while the consumption of sulfuric acid and other operating costs increases. These blocks need frequent repair and restoration and an additional enhancement of the host rocks permeability [12]. In some cases, conducting costly, difficult and complex handling using drilling installations does not yield a positive result. Difficult geological conditions of uranium occurrence such as: deep occurrence, clay content $(>20 \%)$ and carbonate content $(>1.5-$ $2 \%$ ) of the host rocks, filtration heterogeneity of the productive horizon, etc. are characteristic for deposits, confined to the Syrdarya depression.

Literature review. State-of-the-art research focused on improvement of well extraction of uranium ores comprises a wide range of scientific problems. The authors of [13] analyze a set of issues related to application of geotechnological 3D modelling for increasing efficiency of uranium underground leaching. To optimize the patterns of drilling in the ore intervals, it is proposed to use mathematical models describing predictive scenarios of adjusting blocks with probable variants of geotechnological processes development for the purpose of analysis and adopting the most efficient and acceptable flowback option. Despite the logical structural scheme of geotechnological modelling, the work is based on standard computing parameters of distribution of pressures, filtration rates and convective 
mass-transfer. The complexity of modelling physical and chemical parameters in changeable litho-morphological conditions of the productive horizon is not taken into account.

The authors of [14] describe a number of measures to improve underground leaching of uranium by developing the process of the formation hydraulic fracturing using surfaceactive agents (SAA). The method is based on increasing permeability of the productive horizon by creating excessive pressure in it and adding SAA. The study revealed that all SAA solutions reduce surface tension of the solution by $79-96 \%$ [15]. Pumping mud through the technological well into the formation results in distribution of pressures and creation of additional fracturing of matrix rock, which increases geotechnological parameters of producing blocks. However, such method for intensifying uranium underground leaching is applicable only to uranium deposits whose orebody comprises hard or solid rocks. The principal ore-bearing rocks of uranium deposits in Kazakhstan Republic mined by underground leaching systems consist of sands with clay veins where the solution is filtered through capillars and pores.

In [16], the author analyzes the results of experimental research into intensification of uranium leaching with addition of ammonium bifluoride in conditions of sulfuric acid leaching of uranium. The method is based on feeding sulfuric acid solution with addition of ammonium bifluoride into the nearfiltering zone of the well, which results in exchange reaction with formation of hydrofluoric acid. The material presented in this work is important for considering ammonium bifluoride as an efficient solvent of sediments in conditions of uranium ores well extraction. However, the method of cyclic operations in the well involving the solvent feeding and disposal of the productive horizon reduces the index of the well utilization and increases the period of producing blocks operation, which eventually increases the cost of the final product.

The author of [17] focuses on intensification of uranium underground leaching using oxidizer (hydrogen peroxide) added to the leaching solution. Using hydrogen peroxide is explained by its availability and strong oxidizing effect. However, using this solvent in formation seepage deposits of Kazakhstan Republic is not feasible because of the depth of uranium orebody occurrence and high pressure of the formation waters. When hydrogen peroxide is solved in the leaching solution, the resulting water complex is not stable and its disintegration causes gas emission.

Methods. To study mineralogical characteristics of sediments impeding the process of uranium well extraction in laboratory conditions, we have selected samples of colmatants from the deposit in the Syrdarya depression. X-ray phase analysis was used to determine peculiarities of sediments formation and their qualitative and quantitative parameters which are presented in Table 1.

Quantitative and qualitative parameters of the main sedimentation are shown in Table 1.

Table 1

Mineral composition of sediments of uranium deposits in Syrdarya depression

\begin{tabular}{|l|c|c|}
\hline Name of the component & Chemical formula & Amount, \% \\
\hline Ankerite & $\mathrm{Ca}(\mathrm{Mg} \mathrm{Fe} \mathrm{Mn})\left(\mathrm{CO}_{3}\right)_{2}$ & $10-50$ \\
\hline Dolomite & $\mathrm{Ca} \mathrm{Mg} \mathrm{Fe}\left(\mathrm{CO}_{3}\right)_{2}$ & $10-50$ \\
\hline Quartz & $\mathrm{SiO}_{2}$ & $2-30$ \\
\hline Aluminum phosphate & $\mathrm{Al}_{\left(\mathrm{PO}_{4}\right)}$ & $2-15$ \\
\hline Iron oxide & $\mathrm{Fe}_{3} \mathrm{O}_{4}$ & $2-15$ \\
\hline Magnesium sulfate & $\mathrm{MgS}$ & $2-25$ \\
\hline $\begin{array}{l}\text { Calcium aluminum } \\
\text { hydroxide }\end{array}$ & $\mathrm{CaAl}_{2}\left((\mathrm{OH})_{8}\left(\mathrm{H}_{2} \mathrm{O}\right)_{2}\right)$ & $1-30$ \\
\hline
\end{tabular}

Studies of sedimentary formations when mining the Syrdarya group of deposits show the sedimentation of many components including calcium, iron, magnesium, and calcium and magnesium carbonate hydroxides, sand, and clay. The predominance of carbonate sedimentation (from 10 to $50 \%$ ) is due to the high content of carbonate rock-forming minerals in the productive horizon. The presence of quartz, aluminum, and magnesium in the range of $2-30 \%$ indicates dissolution and transfer of feldspar and clay minerals by a solvent flow. The deposition of many components proves the diversity of the processes taking place in the ore-bearing rocks during the sulfuric acid leaching of uranium and complex sedimentation [18].

A complex of multifunctional chemical reagents was selected to intensify the processes occurring during well extraction of uranium in complex mining and geological conditions based on the study of the nature of chemical sedimentation and analysis of the main rock-forming minerals of the productive horizon. The effectiveness of a complex of chemical reagents is determined by its composition and is selected depending on geological features of the productive horizon and quantitative and qualitative characteristics of the formed sediments. The chemical reagents included in the complex have the dissolving ability of the primary carbonate and secondary sedimentation, contribute to active clay release and the creation of additional flows in the porous space of the formation, and also have a high oxidizing ability of $\mathrm{Fe}^{2+}$ to $\mathrm{Fe}^{3+}$ at high $\mathrm{pH}$ values to prevent repeated sedimentation. Intensification of well extraction of uranium using a complex of chemical reagents will allow increasing the rate of mining producing blocks and reducing the cost of the final product.

The study on the effectiveness of impact of the chemical reagent complex was carried out on a geotechnological field of a uranium deposit in the Syrdarya depression during experimental work. The experiments were conducted in geotechnological wells with low time between overhaul (TBO) values and insufficient production by PS, as well as in wells with low uranium content in the productive solution (PS). During semiindustrial tests, specifically selected chemical reagents were fed to the productive horizon through the well collars of selected technological wells with simultaneous injection of leaching solution (LS) into them, until the calculated spreading radius of the solutions from the well filter was achieved. Further, after the injection of the required amount of chemical reagents and LS, compressor pumping was conducted in the production wells and they were put into service. The injection wells were in operation under the pressure of LS. The selection of chemical reagents was carried out according to the characteristics corresponding to the task set for each agent in the complex geological conditions of the sulfuric acid leaching of uranium. The effectiveness of the impact of a chemical reagent on intensification of well extraction of uranium was determined by the results of monitoring and analysis of geotechnological parameters before and after the experimental work. The equipment and the outline of supplying chemical reagents to the productive horizon is shown in Fig. 1.

Equipment for preparing and supplying chemical reagent solutions consists of a tank and a pump made of corrosionresistant material, because they are in contact with LS fortified with sulfuric acid. The LS simultaneously injected into the wells ensured the distribution of chemical solutions in the productive horizon within the effective spreading radius limited at the top and the bottom by impermeable rocks. Spreading and dosing of solutions was carried out and regulated by a pumping unit and stop valves (Fig. 1).

The intensity of mining opened reserves of producing blocks depends on the PS productivity of recovery wells and the content of uranium in the solution, taking into account the utilization rate of the wells. In this regard, monitoring of geotechnological parameters of wells before and after conducting experimental work included daily measurements of average 


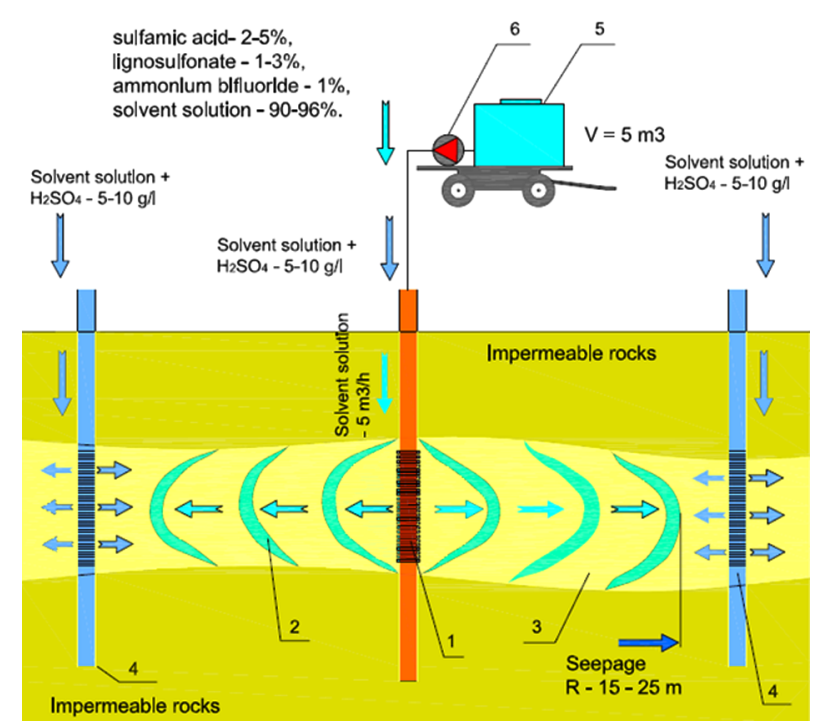

Fig. 1. Outline of chemical reagents supply into the productive horizon:

1 - filter column of extraction well; 2 - chemical reagent solution spreading in the productive horizon; 3 - colmataged productive horizon; 4 - filter column of injection wells; 5 - reservoir for preparing chemical reagent solutions; 6 - pump for supplying chemical reagents

daily well production data for the PS, as well as weekly determination of the uranium content in the PS, $\mathrm{pH}$ and $\mathrm{eH}$ levels of iron salts and residual acidity. After that, the wells were averaged to monthly average values shown in Table 2.

Monitoring of geotechnological parameters and detailed analysis of the content of uranium, iron salts, $\mathrm{pH}$ and $\mathrm{eH}$ values in the PS, before and after processing, shows the actual state of the production process in the selected well. The content of uranium in the PS before processing does not exceed $30 \mathrm{mg} / \mathrm{l}$, at high $\mathrm{pH}$ values of the solution (5.9-6.6), due to clogging of the porous space of the productive horizon, neutralization of sulfuric acid and the influx of formation water. Stable well flow rates within the design value of $8.0 \mathrm{~m}^{3} / \mathrm{h}$ confirm this assumption. A stable and continuous increase in the uranium content in the PS from 36 to $146 \mathrm{mg} / \mathrm{l}$ and a decrease in the $\mathrm{pH}$ of the solution $(2.3-4.8)$ caused by exposure to chemical reagents are observed after the well treatment. However, during the ninth month of monitoring, the uranium content in the PS began to decrease gradually from 120 to $38 \mathrm{mg} / \mathrm{l}$, returning to the previous $\mathrm{pH}$ values of the solution, caused by neutralization of the introduced chemical reagents due to repeated clogging of the porous space in the productive horizon by sedimentation.
Gradual intensification of uranium well extraction process and an increase in the duration of the well non-interrupted operation is due to the gradual destruction of the geochemical barrier under the synergistic effect of chemical reagents in a porous medium. The synergistic effect of a chemical reagent complex allows increasing the rate of mining a producing block and reducing the specific consumption of sulfuric acid for uranium leaching in difficult geological conditions.

Results. Redox reactions and filtration processes occurring in the formation largely determine the efficiency of well extraction of uranium mining technology, the completeness of metals extraction into the solution, the specific consumption of chemical reagents, energy consumption and overall technical, economic and environmental indicators of production [19]. According to the obtained results, Fig. 2 shows the graph describing the dynamics of uranium concentration changes over time depending on the $\mathrm{pH}$ level in the PS.

As can be seen from Fig. 2, the initial $\mathrm{pH}$ values of the solution were at a high level of 6.55 , which indicates the dilution of productive solutions by formation waters, because of the creation of a geochemical barrier in the formation impeding the leaching solution flow lines. Low values of uranium content in PS confirm the assumptions of the solvent blocking by colmatage. After feeding solutions of multifunctional chemical reagents into the productive horizon, a noticeable decrease and fluctuation in the solution $\mathrm{pH}$ values occur within the level of 2.33-5.54 caused by the interaction of multifunctional chemical reagents in the formation. Fluctuations in the $\mathrm{pH}$ level in the solution are caused by the influence of the LS front movement in the porous space of the productive horizon. The first $\mathrm{pH}$ decrease is caused by the approach of LS containing chemicals delivered to the formation through the well collar, the second decrease is caused by the LS front effect from injection wells. The two-stage increase in the uranium content in the PS is due to the restoration of filtration characteristics and the flow line of the productive horizon. Subsequent well testing shows a gradual increase and stabilization of the previous (pre-experimental) $\mathrm{pH}$ value of 6.21, which confirms the termination of the interaction of the chemical reagent complex in the productive horizon and restoration of geochemical barrier and clogging of the formation.

Dynamics of uranium content change over time depending on the Eh level in the PS during the period from the first to the fourth month of the well parameters monitoring testifies that Eh values were stable at the level of $300-308 \mathrm{mV}$, while the increase in uranium content in PS is caused by transition of uranium soluble minerals into the solution. During the fifth month of monitoring, there is an increase in Eh level to $380 \mathrm{mV}$ due to the approach of LS front from the injection

Data from monitoring of geotechnological parameters of wells before and after conducting experimental research

\begin{tabular}{|c|c|c|c|c|c|c|c|c|}
\hline \multirow{3}{*}{ Parameter } & \multicolumn{4}{|c|}{ Before treatment } & \multicolumn{4}{|c|}{ After treatment } \\
\hline & \multicolumn{8}{|c|}{ Month } \\
\hline & 1 & 2 & 3 & 4 & 5 & 6 & 7 & 8 \\
\hline$C \mathrm{U}, \mathrm{mg} / \mathrm{l}$ & 28 & 20 & 14 & 102 & 96 & 146 & 120 & 38 \\
\hline$Q, \mathrm{~m}^{3} / \mathrm{h}$ & 8.0 & 7.8 & 7.8 & 8.0 & 8.0 & 8.0 & 8.0 & 7.8 \\
\hline $\mathrm{pH}$ & 6.6 & 6.4 & 5.9 & 4.8 & 5.5 & 2.78 & 5.6 & 6.2 \\
\hline $\mathrm{Fe}^{3+}, \mathrm{mg} / \mathrm{l}$ & 76 & 76 & 84 & 84 & 226 & 167 & 279 & 195 \\
\hline $\mathrm{Fe}^{2+}, \mathrm{mg} / \mathrm{l}$ & 200 & 200 & 140 & 140 & 112 & 28 & 307 & 446 \\
\hline $\mathrm{SO}_{4}^{2-}, \mathrm{g} / \mathrm{l}$ & 8.38 & 7.42 & 8.88 & 7.44 & 6.72 & 6.48 & 12.48 & 14.64 \\
\hline eH & 300 & 300 & 305 & 308 & 380 & 167 & 140 & 140 \\
\hline
\end{tabular}




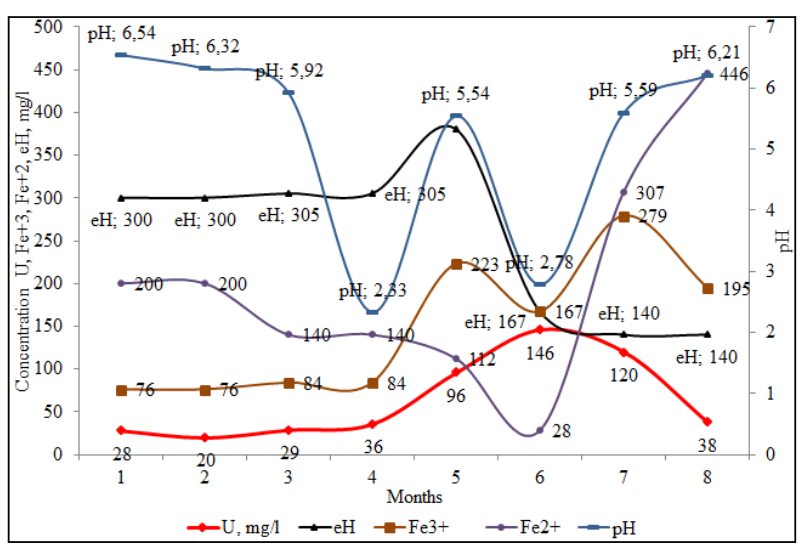

Fig. 2. Dynamics of uranium content change in PS depending on the $\mathrm{pH}, \mathrm{Eh}, \mathrm{Fe}^{3+}, \mathrm{Fe}^{2+}$ level

wells and intensification of redox processes in the productive horizon. Further monitoring shows decrease in the solution Eh values from 380 to $167-140 \mathrm{mV}$, which is the evidence of the redox process attenuation in the formation due to colmatage.

Prior to the experimental work during the four months of monitoring, the content of $\mathrm{Fe}^{2+}$ was consistently low at the level of $200-140 \mathrm{mg} / \mathrm{l}$, due to sedimentation of $\mathrm{Fe}^{2+}$ in the formation caused by dilution of PS formation water and an increase in $\mathrm{pH}$. During the fifth and sixth months of observations, the content of $\mathrm{Fe}^{2+}$ decreased from 140 to $28 \mathrm{mg} / \mathrm{l}$, caused by the action of a complex of multifunctional chemical reagents in the formation and massive oxidation of $\mathrm{Fe}^{2+}$ to $\mathrm{Fe}^{3+}$. During the ninth month of control, we saw a sharp increase in the content of $\mathrm{Fe}^{2+}$ to $446 \mathrm{mg} / \mathrm{l}$, due to the termination of $\mathrm{Fe}^{2+}$ oxidation in the formation. A further decrease in the content of $\mathrm{Fe}^{2+}$ in the PS to $84 \mathrm{mg} / 1$ indicates the deposition of iron in the productive horizon and clogging of the porous space.

The schedule of changes in the uranium content over time depending on the content of $\mathrm{Fe}^{3+}$ in the PS shows that its content in the solution remains unchanged during four months of testing. During the fourth - fifth months of monitoring, there is a noticeable increase in the content of $\mathrm{Fe}^{3+}$ in the PS to the level of $223 \mathrm{mg} / \mathrm{l}$, caused by the effect of a multifunctional chemical reagent complex in the formation and massive oxidation of $\mathrm{Fe}^{2+}$ to $\mathrm{Fe}^{3+}$. From the fifth to the sixth month of observations, there is a sharp decrease in the concentration of $\mathrm{Fe}^{3+}$ in the PS to $167 \mathrm{mg} / \mathrm{l}$; however, during the eighth month of control, we observed a noticeable increase in the content of ferric iron in the solution to $279 \mathrm{mg} / \mathrm{l}$, due to the massive oxidation of $\mathrm{Fe}^{2+}$ to $\mathrm{Fe}^{3+}$. A further decrease in the iron content in the PS indicates a drop in the redox activity of the solution in the productive horizon, caused by the re-clogging of the productive horizon.

Leaching of uranium under conditions of natural permeability depends on a number of factors, including the primary and secondary mineralization of uranium, the average side concentration of uranium in the formation, the composition and grain size of sand, the average carbonate content in the formation, as well as the conditions of opening, acidification and leaching of the productive horizon. Values of mining blocks and geotechnological parameters of wells do not reach design values, due to the low uranium content in the PS and frequent well shutdowns for remediation in difficult mining and geological conditions. It can be seen from Fig. 2 that at the beginning of the experiment, the uranium content in the PS was in the range of $20-30 \mathrm{mg} / \mathrm{l}$, and the $\mathrm{pH}$ level was high 6.55, the content of $\mathrm{Fe}^{3+}$ and $\mathrm{Fe}^{2+}$ was low 84-140 mg/l, respectively, and the Eh level was at a stable level of $305 \mathrm{mV}$, which indicates the formation of a geochemical barrier that impedes the flow of the leach in the seam. The subsequent sup- ply of a chemical reagent complex showed the restoration of the initial permeability and a steady increase in the $\mathrm{Fe}^{3+} / \mathrm{Fe}^{2+}$ ratio which has a directly proportional effect on the concentration of uranium in the PS at high $\mathrm{pH}$ values. A steady increase in the uranium content in the productive solution from 30 to $146 \mathrm{mg} / \mathrm{l}$ indicates oxidation of $\mathrm{U}^{4+}$ to $\mathrm{U}^{6+}$ and high efficiency of the used complex.

Conclusions. The results of X-ray phase analyses indicate that clogging deposits are of chemical type, which are multicomponent and may contain calcium, iron, magnesium salts and their hydroxides, calcium and magnesium carbonates, as well as sand and clay. They precipitate on the surface of filters and in the pores of adjacent aquifers due to gravity, or are adsorbed due to the impact of surface tension forces. Precipitation of chemical formations on the filtering path of the leaching solution negatively affects the leaching process, blocking the access of LS. Formation of a geochemical barrier in the productive horizon deteriorates the process of mining producing blocks, thereby increasing the cost of the final product. The intensification of uranium well extraction, using an effective complex of chemical reagents, is based on the effective destruction of the geochemical barrier and the subsequent increase in exchange reactions of the porous medium.

The results of experimental research into uranium well extraction intensification using a chemical complex of multifunctional reagents indicate the effectiveness of the method. Gradual intensification of the uranium leaching process and the increase in the uranium content in solutions is due to the gradual destruction of the geochemical barrier, the restoration of the initial permeability of the productive horizon under the synergistic effect of chemical reagents. The use of a chemical reagent complex with a synergistic effect allows increasing the rate of mining producing blocks and reducing the specific consumption of sulfuric acid for uranium leaching in difficult geological conditions

Intensification of uranium well extraction in complex mining and geological conditions should be carried out using a complex of multifunctional chemical reagents depending on the composition of ore-bearing rocks. The supply of effective concentrations of chemical reagents to the leaching solution in combination with traditional methods of well regeneration intensifies uranium leaching process.

\section{References.}

1. Pivnyak, G. G., Pilov, P. I., Bondarenko, V. I., Surgai, N. S., \& Tulub, S. B. (2005). Development of coal industry: The part of the power strategy in the Ukraine. Gornyi Zhurnal, (5), 14-17. 2. Bondarenko, V., Symanovych, G., \& Koval, O. (2012). The mechanism of over-coal thin-layered massif deformation of weak rocks in a longwall. Geomechanical Processes During Underground Mining - Proceedings of the School of Underground Mining, 41-44. https://doi.org/10.1201/b13157-8.

3. Lozynskyi, V., Saik, P., Petlovanyi, M., Sai, K., Malanchuk, Z., \& Malanchuk, Y. (2018). Substantiation into mass and heat balance for underground coal gasification in faulting zones. Inzynieria Mineralna, 19(2), 289-300. https://doi. org/10.29227/IM-2018-02-36.

4. Ilankoon, I. M. S. K., Tang, Y., Ghorbani, Y., Northey, S., Yellishetty, M., Deng, X., \& McBride, D. (2018). The current state and future directions of percolation leaching in the Chinese mining industry: Challenges and opportunities. Minerals Engineering, (125), 206-222. https://doi.org/10.1016/j. mineng.2018.06.006.

5. Bondarenko, V. I., \& Sai, K.S. (2018). Process pattern of heterogeneous gas hydrate deposits dissociation. Naukovyi Visnyk Natsionalnoho Hirnychoho Universytetu, (2), 21-28. https://doi.org/10.29202/nvngu/2018-2/4.

6. Molchanov, A. A., \& Demekhov, Yu. V. (2014). Increasing the efficiency of uranium production from hydatogenous deposits developed by drillhole in situ leachingin the Republic of 
Kazakhstan (by the example of eastern Mynkuduk deposit). Aktuaknyie Problemy Uranovoi Promyshlennoti, 92-98.

7. Petlovanyi, M., Kuzmenko, O., Lozynskyi, V., Popovych, V., \& Sai, K. (2019). Review of man-made mineral formations accumulation and prospects of their developing in mining industrial regions in Ukraine. Mining of Mineral Deposits, 13(1), 24-38. https://doi.org/10.33271/mining13.01.024.

8. Bini, C., Maleci, L., \& Wahsha, M. (2017). Mine waste: assessment of environmental contamination and restoration. Assessment, Restoration and Reclamation of Mining Influenced Soils, 89-134. https://doi.org/10.1016/b978-0-12-8095881.00004-9.

9. Kuzmenko, O., Petlyovanyy, M., \& Heylo, A. (2014). Application of fine-grained binding materials in technology of hardening backfill construction. Progressive Technologies of Coal, Coalbed Methane, and Ores Mining, 465-469. https:// doi.org/10.1201/b17547-79.

10. Khawassek, Y. M., Taha, M. H., \& Eliwa, A. A. (2016). Kinetics of leaching process using sulfuric acid for Sella uranium ore material, South Eastern Desert. Egypt International Journal of Nuclear Energy Science and Engineering, (6), 62-73. https://doi.org/10.14355/ijnese.2016.06.006.

11. Chen, J., Zhao, Y., Song, Q., Zhou, Z., \& Yang, S. (2018). Exploration and mining evaluation system and price prediction of uranium resources. Mining of Mineral Deposits, 12(1), 85-94. https://doi.org/10.15407/mining12.01.085.

12. Joint, A. (2018). Uranium 2018. Resources, Production and Demand. Nuclear Energy Agency. https://doi.org/10.1787/ uranium-2018-en.

13. Nikitina, Yu. G., Poyezzhayev, I.P., \& Myrzabek, G.A. (2019). Improvement of opening schemes of wellfields to optimize the cost of mining uranium. Gornyi Vestnik Uzbekistana, (1), 6-11.

14. Alikulov, S.S., Sobirov, Z., \& Khaidarova, M.E. (2018). Research and implementation of the methods of limiting the diffluence of product solutions and the intensification of underground leaching workflows. Gornyi Zhurnal, (3), 100-106. https://doi.org/10.21440/0536-1028-2018-3-100-106.

15. Bondarenko, V., Svietkina, O., \& Sai, K. (2018). Effect of mechanoactivated chemical additives on the process of gas hydrate formation. Eastern-European Journal of Enterprise Technologies, 1(6(91)), 17-26. https://doi.org/10.15587/17294061.2018.123885.

16. Yusupov, K.A., Elzhanov, E. A., Aliev, S. B., \& Dzhakupov, D.A. (2017). Application of ammonium bifluoride for chemical treatment of wells in underground uranium leaching. Gornyi Zhurnal, (4), 57-60. https://doi.org/10.17580/ gzh.2017.04.11

17. Vasilenok, O.P., Ruziev, B.T., \& Ivanova, I. A. (2018). Role and effect of in-situ leach uranium oxidizers in by-recovery of rhenium. Gornyi Zhurnal, (9), 74-77. https://doi. org/10.17580/gzh.2018.09.11.

18. Mataev, M.M., Rakishev, B.R., \& Kenzhetaev, G.S. (2017). The impact of ammonium bifluoride complex on colmataging formations during the process ofin situ uranium leaching. International Journal of Advanced Research, 5(2), 147-154. https://doi.org/10.21474/ijar01/3126.

19. Uralbekov, B., Burkitbayev, M., \& Satybaldiev, B. (2015). Evaluation of the effectiveness of the filtration leaching for uranium recovery from uranium ore. Chemical Bulletin of $\mathrm{Ka}$ zakh National University, (3), 22-27. https://doi.org/10.15328/ cb656.

\section{Вплив комплексу хімічних реагентів на інтенсифікацію свердловинного видобутку урану}

\author{
Б. P. Ракішев $^{1}$, B. I. Бондаренко ${ }^{2}$, M. М. Матаєв ${ }^{3}$, \\ Ж. С. Кенжетаєв ${ }^{1}$
}

1 - Казахський національний дослідний технічний університет імені К. І. Сатпаєва, м. Алмати, Республіка Казахстан, e-mail:kzhiger@yahoo.com

2 - Національний технічний університет „Дніпровська політехніка“", м. Дніпро, Україна, e-mail: v_domna@yahoo.com 3 - ТОВ „Інститут високих технологій“", м. Алмати, Республіка Казахстан, e-mail: mataev_06@mail.ru

Мета. Встановити вплив спеціальних хімічних реагентів, що подаються у складі вилуговуючих розчинів, на геотехнологічні параметри при свердловинному видобутку урану. Виявити можливість застосування методу для підвищення ефективності свердловинної розробки уранових руд, що заснований на інтенсифікації геотехнологічних процесів підземного вилуговування урану. Забезпечити проектну продуктивність експлуатаційних блоків та повноту вилучення металу з них, зменшити й попередити утворення осаду в пористому середовищі, знизити питомі витрати сірчаної кислоти, електроенергії, трудових затрат та інших виробничих витрат у процесі свердловинного видобутку урану.

Методика. Включає послідовне проведення літературного пошуку, лабораторних і практичних робіт в реальних умовах. Відбір проб та вивчення в лабораторних умовах рентгенофазовим методом мінералогічних характеристик осадкоутворення з родовищ Сирдар'їнської депресії. Підбір хімічних реагентів та опробовування на геотехнологічних свердловинах при проведенні експериментальних робіт в умовах свердловинного видобутку урану. Збір вихідних результатів геотехнологічних параметрів свердловин з наступним проведенням порівняльного аналізу з експериментальними даними.

Результати. Отримані значення параметрів $\mathrm{pH}$ вилуговуючих розчинів у діапазоні від 6,5 до 2,3; виявлене помітне підвищення 3 наступним зниженням значень Eh від 300-380 до 170 мВт; встановлено стабільне збільшення вмісту урану в продуктивному розчині з 29 до 146 мг/л; визначені значення концентрації солей заліза $\left(\mathrm{Fe}^{3+}, \mathrm{Fe}^{2+}\right)$ у продуктивному розчині під дією хімічних реагентів багатофункціонального призначення.

Наукова новизна. Розроблений та обгрунтований метод інтенсифікації свердловинного видобутку урану, заснований на застосуванні нового комплексу хімічних реагентів селективного впливу на урановмісні мінерали, що забезпечує підвищення продуктивності експлуатаційних блоків.

Практична значимість. Раціонально підібрані окислювачі та хімічні реагенти, а також розроблена схема їх подачі в продуктивний горизонт, дозволяють інтенсифікувати розчинення чотирьохвалентного урану в складних гірничо-геологічних умовах шляхом підземного вилуговування й підвищити продуктивність експлуатаційного блоку.

Ключові слова: свердловинний видобуток, уранова руда осадкоутворення, рентгенофазовий аналіз, хімічні реагенти

\section{Влияние комплекса химических реагентов на интенсификацию скважинной добычи урана}

\section{Б. Р. Ракишев ${ }^{1}$, В. И. Бондаренко ${ }^{2}$, М. М. Матаев $^{3}$, Ж. С. Кенжетаев ${ }^{1}$}

1 - Казахский национальный исследовательский технический университет имени К. И. Сатпаева, г. Алматы, Республика Казахстан, e-mail: kzhiger@yahoo.com

2 - Национальный технический университет „Днепровская политехника“, г. Днепр, Украина, e-mail: yahoo.com

3 - ТОО „Институт высоких технологий“, г. Алматы, Республика Казахстан, e-mail: mataev_06@mail.ru 
Цель. Установить влияние специальных химических реагентов, подаваемых в составе выщелачивающих растворов, на геотехнологические параметры при скважинной добыче урана. Выявить возможность применения метода для повышения эффективности скважинной разработки урановых руд, основанной на интенсификации геотехнологических процессов подземного выщелачивания урана. Обеспечить проектную производительность эксплуатационных блоков и полноту извлечения металла из них, уменьшить и предупредить образование осадков в пористой среде, снизить удельные расходы серной кислоты, электроэнергии, трудовых затрат и других производственных расходов в процессе скважинной добычи урана.

Методика. Включает последовательное проведение литературного поиска, лабораторных и практических работ в реальных условиях. Отбор проб и их изучение в лабораторных условиях рентгенофазовым методом на примере месторождений Сырдарьинской депрессии. Подбор химических реагентов и опробование на геотехнологических скважинах при проведении экспериментальных работ в условиях скважинной добычи урана. Сбор выходных результатов геотехнологических параметров скважин с последующим проведением сравнительного анализа с экспериментальными данными.

Результаты. Получены значения параметров рН выщелачивающих растворов в диапазоне от 6,5 до 2,3; вы- явлено заметное повышение с последующим понижением значений Eh от 300-380 до 170 мВт; установлено стабильное увеличение содержания урана в продуктивном растворе с 29 до 146 мг/л; определены значения концентрации солей железа $\left(\mathrm{Fe}^{3+}, \mathrm{Fe}^{2+}\right)$ в продуктивном растворе под действием химических реагентов многофункционального назначения

Научная новизна. Разработан и обоснован метод интенсификации скважинной добычи урана, основанный на применении нового комплекса химических реагентов селективного воздействия на ураносодержащие минералы, обеспечивающий повышение производительности эксплуатационных блоков.

Практическая значимость. Рационально подобранные окислитель и химических реагенты, а также разработанная схема их подачи в продуктивный горизонт, позволяют интенсифицировать растворение четырехвалентного урана в сложных горно-геологических условиях путем подземного выщелачивания и повысить производительность эксплуатационного блока.

Ключевые слова: скважинная добыча, урановые руды, осадкообразование, рентгенофазовый анализ, химические реагенты

Recommended for publication by I. A. Kovalevska, Doctor of Technical Sciences. The manuscript was submitted 23.02.19. 